\title{
Community monitoring in a tourism-dependent economy
}

\author{
J. Aguero ${ }^{1}$, S. Conway ${ }^{2} \&$ I. Navis ${ }^{3}$ \\ ${ }^{1}$ Applied Analysis, USA \\ ${ }^{2}$ Urban Environmental Research, LLC, USA \\ ${ }^{3}$ Clark County, Nevada, USA
}

\begin{abstract}
Clark County, Nevada, home to the world-famous Las Vegas Strip, is arguably the most tourism-dependent economy in the United States. Such dependence has both positive and negative economic, fiscal, and social ramifications. The issue of core-industry sustainability is particularly germane, as $30 \%$ of the region's workforce is directly employed in the leisure and hospitality industry and where that sector accounts for the lion's share of state and local tax collections. This paper discusses the evolution of the Clark County, Nevada Monitoring Program, a broad-based community indicator system originally designed to monitor the potential impacts of transportation and storage of high-level nuclear waste at a proposed nuclear waste repository. Further, the paper focuses on the program's applications in evaluating diversity issues as they relate to sustainability in this tourism-dependent economy.
\end{abstract}

Keywords: community monitoring, sustainable tourism, Las Vegas, economic impact, nuclear waste, community indicators.

\section{Introduction}

Since 1988, Clark County, Nevada ("Clark County" or "the County") has been designated by the Department of Energy ("DOE") as an "Affected Unit of Local Government" ("AULG"). The AULG designation is an acknowledgement by the federal government that activities associated with the Yucca Mountain proposal could result in considerable impacts on Clark County residents and the community as a whole. As an AULG, Clark County is authorized to identify 
"[a]ny potential economic, social, public health and safety, and environmental impacts of a repository" 42 U.S.C. Section 10135(c)(1)(B)(i). under provisions of the Nuclear Waste Policy Act Amendments.

In 2004, Clark County's Nuclear Waste Division and its consultant team implemented the original Yucca Mountain Monitoring Program. The Yucca Mountain Monitoring Program was designed in furtherance of the Clark County's Impact Assessment Report [1]. This seminal work on the potential impacts of the transportation and storage of high-level nuclear waste at the Yucca Mountain Nuclear Waste Repository analyzed economic, fiscal, environmental, and public safety considerations. The Yucca Mountain Monitoring Program was developed to provide a foundation for on-going policy discussions and a baseline from which economic, fiscal, or social changes could be monitored over time. Importantly, it also functions as an "early-warning system" identifying statistically-significant trend shifts. In other words, it provides form to the functions and responsibilities borne by Clark County as an AULG.

\section{The Clark County Monitoring Program}

The Clark County Monitoring Program ("the Program" or "the Monitoring Program") is segmented into five primary sections: economic, fiscal, social, environmental, and public health and safety. The indicators contained in each of these sections can be viewed as analysis tools; and, in turn, www.monitoringprogram.com can be viewed as a tool box. The Internet-based information access point is designed simply, providing easy access to both the novice and advanced user. The site's homepage provides an access point to the majority of information analyzed on a recurring basis.

Perhaps the most important enhancement made to the monitoring program since its inception is its expanded scope and purpose during the past 18 months. The process as originally conceived and outlined (Conway and Navis, [2]), has been effectively integrated into the four primary comprehensive planning functions: visioning, planning, implementing and assessment. Originally designed, developed, and focused on assessing the impacts of transporting highlevel nuclear waste through Clark County's population centers, the utility of the Program and the information it contains adds value at each turn in the process (see Figure 1).

\section{Monitoring trends in tourism and economic diversity}

There is little argument that the Nevada economy lacks diversity. Employment data routinely tracked by the Monitoring Program suggest that just less than $30 \%$ of the region's workforce is directly employed in the hospitality and leisure sector, a figure roughly consistent with the concentration reported a decade ago and one that is more than three times the national average (see Figure 2). Including direct, indirect and induced employment, the leisure and hospitality 
sector has been estimated to support between 50 and $60 \%$ of the state's labor force (Bybee and Aguero, [3]). This means that an estimated one-half of all employees depend on the health of Nevada's tourism industry for their jobs. This arguably makes Nevada the narrowest economy of its size in the United States.

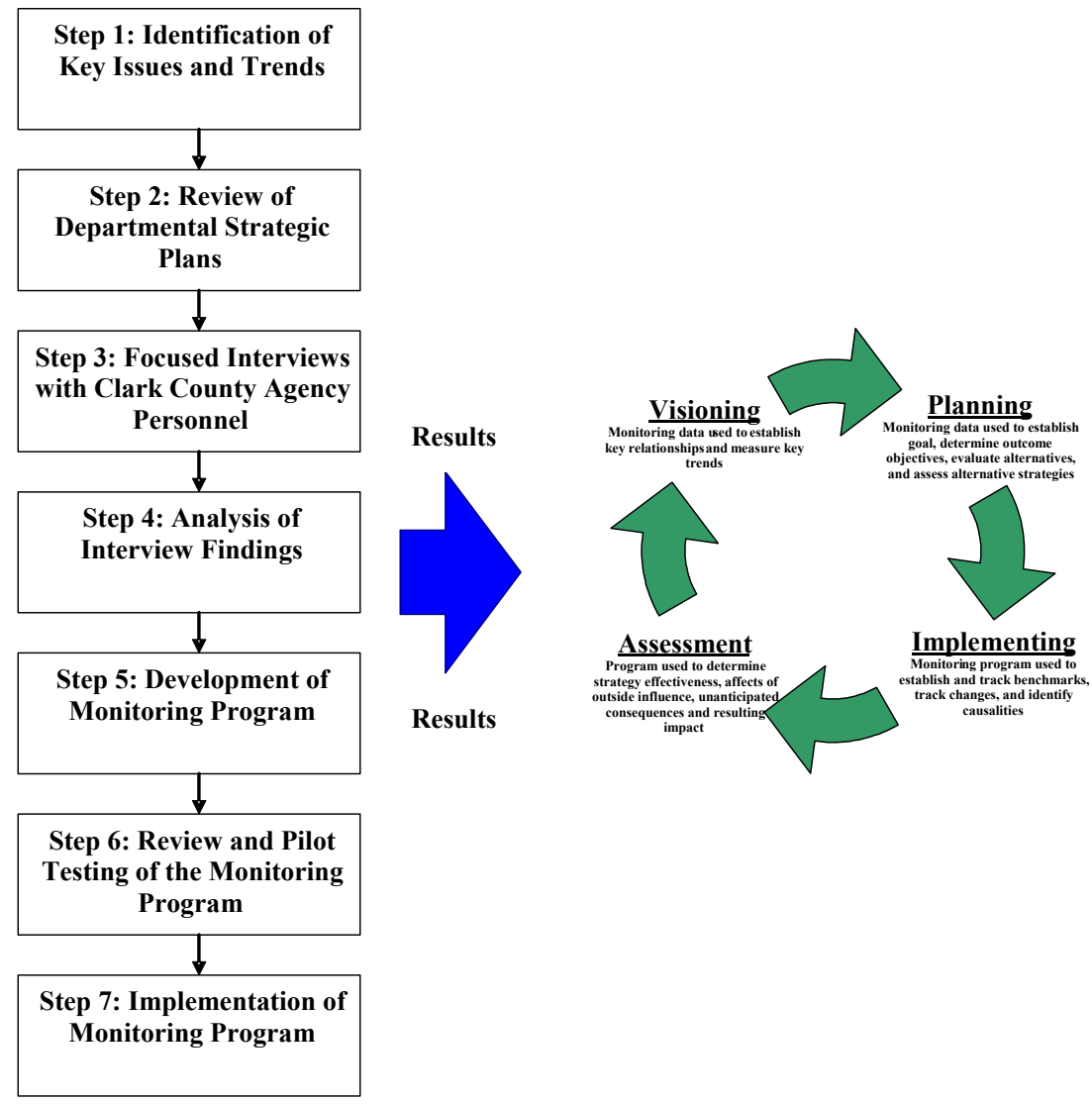

Figure 1: Monitoring program integration diagram.

Experts who have been tasked with studying the impacts of growth have long recognized that diversifying Clark County's economy is essential to its sustainability. In its 1997 report, "Livable Las Vegas: Managing Growth in the Las Vegas Valley," The Washington, D.C. based Urban Land Institute recognized the region is "vulnerable to any shifts that take place within the industry, and the industry itself could be seriously damaged by a future national recession" (Urban Land Institute, [4]). Similarly, in 1998, the Southern Nevada Strategic Planning Authority, a group of community leaders who came together 
under a legislative mandate to create a 20-year strategic plan for the region, recognized the need to capture data on economic diversity trends, opportunities, and threats. Further, they drew a clear link between quality of life indicators and the potential for success of economic development efforts (Southern Nevada Regional Planning Authority, [5]). The Monitoring Program is uniquely designed to capture shifts in economic and other indicators that provide an "early warning" that adjustments must be made to minimize vulnerability under adverse circumstances.

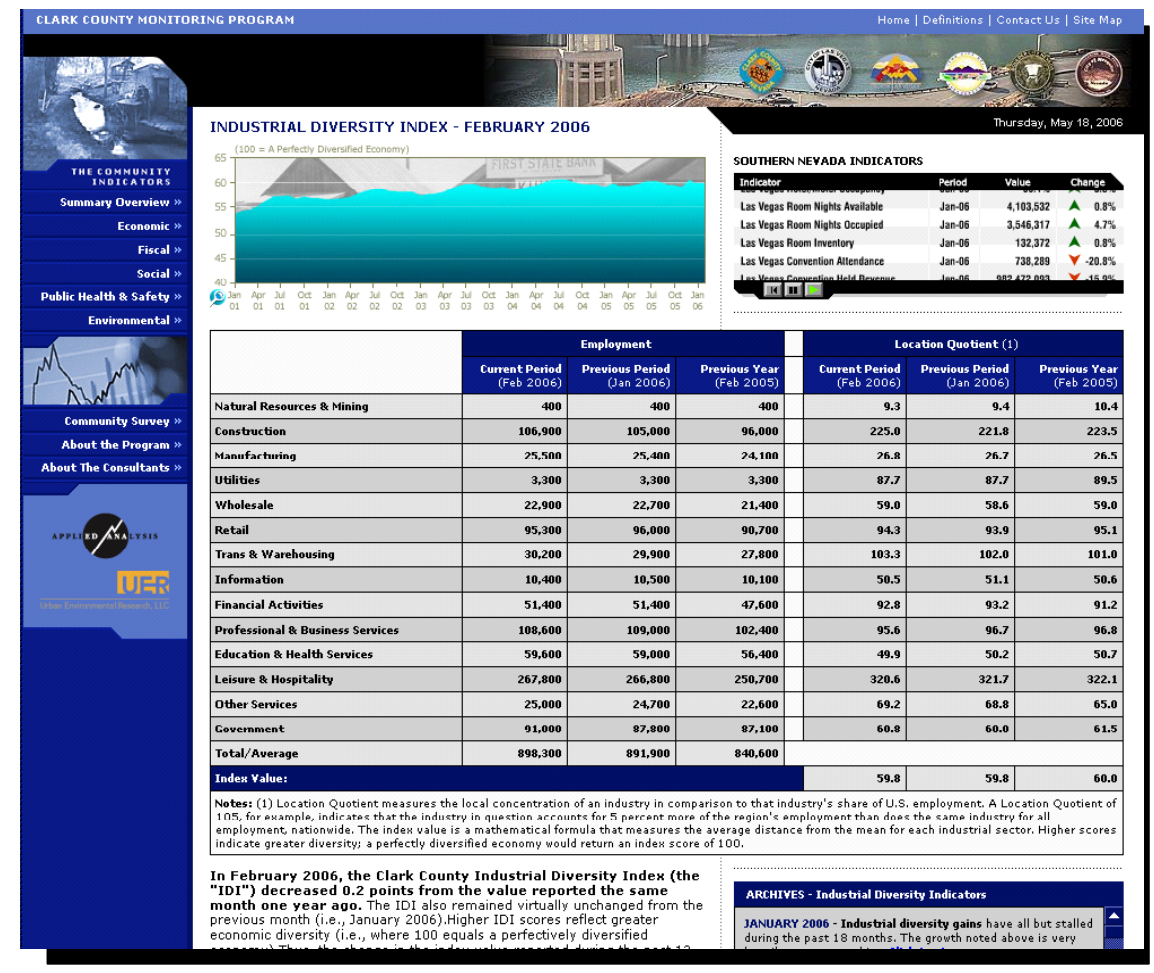

Figure 2: Clark County Monitoring Program: industrial diversity index.

There is some evidence that the Clark County's economy has taken small steps toward diversification. Hotel-casino and gaming employment (a subset of the leisure and hospitality sector) represented as much as $25 \%$ of Southern Nevada's workforce in 1995. Today, it represents approximately $20 \%$. Wage distribution statistics have also followed a similar trend. Worth noting, however, is that these declines not only reflect changes in the overall structure of the regional economy, they also reflect changes in the structure of the gaming/tourism industry itself. The evolution of Nevada's hospitality sector has resulted in more non-gaming expenditures than in years past. The result is that 
tourism dollars are supporting a relatively higher number of jobs in peripheral industries like retail sales and food and beverage businesses. In 2005, gaming revenues represented less than $50 \%$ of all revenues reported by Southern Nevada's casino hotel industry; during most of the 1980s and 1990s that share average greater than 60\% (Nevada Gaming Control Board, [6]). While these numbers are not reflected in the industry-specific employment or wage estimates, they certainly account for at least a portion of the reported decline in the sector's share of total employment

A second, and perhaps stronger argument, is that non-gaming/tourism business and industry have kept pace with the hospitality sector. Where the leisure and hospitality sector has grown at a compounded annual growth rate of $4.5 \%$ during the last ten years, the overall rate of employment growth has been $5.7 \%$. This must be qualified by understanding that the size of Southern Nevada leisure and hospitality sector, is considerably larger than the most other sectors. For example, a ten percent increase in the region's manufacturing sector would generate approximately 2,500 new jobs; a similar increase in the leisure and hospitality sector would generate nearly 27,000 jobs. This point notwithstanding, the fact that non-gaming businesses have not decreased in prominence considering the remarkable gaming/tourism growth reported during the last ten years is a noteworthy economic development consideration.

Understanding that there are indications that the regional economy is more diverse today than it was 10,15 , or 25 years ago, it is impossible to conclude that Southern Nevada has attained any level of economic diversification that would significantly insulate it against a downturn in the gaming/tourism sector. History has taught us well that narrow economies, or those that are highly dependent on a single industry, are more susceptible to economic turmoil. Moreover, economic downturns that occur where narrow economies exist tend to be more far-reaching and long-lasting than those where the economy is more diverse. This is generally the case because the narrow economy becomes susceptible to the business cycle of a single industry. When that industry is up, prosperity stretches across sectors; when that industry is down, it ripples through the community.

As noted above, history is not short on practical applications of this threat. Take for example Texas' dependence on the oil industry in the 1970s. An estimated $28 \%$ of the state's economy was dependent on the oil industry at the height of its reign (San Diego Tribune, [7]; Halkais and Brown, [8]). According to Bernard Weinstein, Director of Southern Methodist University's Center for Enterprising, the industry's downturn in the late-1970s required nothing less than a "structural transformation," which he estimated could take as many as 20 years. Looking back, one observer noted that "there was so much money coming into [Texas] that it became an intoxicant." He continued by stating, "People started believing that it would never end."

A second example of the problems that can arise in economies that lack diversity is Seattle, Washington in the 1960s, 1970s, and 1980s. The area's economy was largely dependent on Boeing Corporation, which represented approximately $19 \%$ of the region's workforce in 1970 (Wallace, [9]). Boeing executed major layoffs around 1970. These layoffs, which were largely the result 
of cyclical changes affecting Boeing's business, rippled through the economy with such force that one Wall Street Journal observer described it as "worse than the height of the Great Depression" (Dow Jones, [10]). A billboard placed on the main highway that announced, "[i]f you are the last person to leave Seattle, please turn off the lights," perhaps best exemplified the magnitude of the impact.

This event was not isolated. By the 1980s Seattle had diversified to the point that significantly fewer of the region's employees worked directly for Boeing Corporation. When Boeing again laid off a significant portion of its workforce, the region's unemployment rate followed suit by more than doubling, from 5 to $11 \%$. It was not until the $1990 \mathrm{~s}$, when four-fifths of the area's economy was "independent of the aerospace giant" that diversification efforts were given credit for helping "offset Boeing cuts" (Chicago Tribune, [11]).

The parallel to the Southern Nevada economy does not go unnoticed. Where Boeing represented an estimated $19 \%$ of the Seattle area's workforce at the height of its dominance, the leisure and hospitality industry currently represents approximately $30 \%$ of Southern Nevada's employment base. Including direct, indirect, and induced employment impacts, the industry supports an estimated 50 to $60 \%$ of the workforce. If any portion of the Seattle experience can be translated to Southern Nevada, a cyclical downturn in the gaming/tourism industry would be nothing less than devastating.

Importantly, tourism-dependent economies are not immune to cyclical changes. This is perhaps best illustrated by Hawaii's troubled economy, specifically in the island of Maui (Blackford [12]; Jones [13]; Ybarra [14]). The island's downturn in tourism that lagged on after the national recession in the early 1990s reportedly doubled the area's unemployment by 1994. The impact of the tourism industry's downturn not only reported social impacts, including increasing instances of homelessness and an estimate that "one out of every five Mauians [was] suffering some food deprivation," but economic turmoil translated into serious fiscal ramifications for the local government. Specifically, falling real estate values were cited as having "slashed" the island's tax revenues.

The historical evidence is overwhelming. It shows clearly and decisively that economies that are dependent on a single industry have a greater vulnerability to elongated and more severe economic downturns. Moreover, because of the interdependent nature of local and regional economies, all sectors become susceptible to the business cycle of the principal industry. To use an Old West analogy -- when the mine dries up, so does the town. This economic trend has not gone unnoticed by scholars, government officials, economists, and other learned market observers. To a great extent, Western economies that evolved during the nineteenth and mid-twentieth centuries were built around monocultures. That is to say, single industries - mining, cattle-raising, wheat-growing, railroading, etc. Economic specialization promoted growth and founded cities. The evolution of the city has shown us that successful modern economies do not abandon the specialization that stimulated growth, but view diversity as the presence of multiple specializations (Malizia et al., [15]).

It has long been theorized that the more diverse a region becomes, the less sensitive it becomes to fluctuations from outside of the region. (Norse, [16]) 
Several studies have since added substance to this theory, showing that diversification not only promotes stability but also enhances the broader goals of economic vitality, growth, and low rates of unemployment (Kort [17]; Wagner and Deller [18]; Malizia et al. [15]; Siegel et al. [19]). In Measuring the Effects of Economic Diversity on Growth and Stability, John Wagner and Steven Deller used a series of econometric equations to show that growth and stability can be simultaneously achieved. The authors suggest that this can occur where policymakers approached the long-run goal of diversification through a series of short-term growth strategies (Wagner and Deller, [18]). These analysts used a complex regional input-output modeling framework, which considered both the size and structure of the regional economy as well as the level of inter-industry linkages to perform their study. The results are cited as establishing a "wider range of policy options," including vertical and horizontal integration through targeting "value-added" industries. Where some of these policies were historically seen as an economic liability, they are shown to simultaneously promote stability and growth in the long term.

Southern Nevada's need for economic diversification has increased due to its phenomenal rate of growth during the last 20 years. Careful studies have decisively shown that there is a relationship between city size, economic diversification, and economic instability (Kort, [17]). Smaller cities tend to have less economic diversification and therefore greater economic instability. In general, larger cities tend to diversify and become more stable. Where they do not, the impacts of economic downturns can be drawn out by the high level of dependence on the highly-concentrated industry. In a study that measured the relationship between diversification and regional economic stability in most U.S. metropolitan areas between 1972 and 1988, the authors similarly concluded that "metropolitan areas that are more diverse experience lower unemployment rates and less instability than areas which are less diverse" (Malizia et al., [15]). This study further argued that both diversity and competitiveness within a region are major factors influencing metro-area growth. These factors were cited as operating through "multiple specializations" in diverse economies, where greater diversity led to increased economic stability.

While both historical evidence and the weight of authority support the conclusion that economic diversification is a sound and prudent public policy, arguments supporting the merits of economic isolationism are not uncommon in Southern Nevada. The logic is as follows: 1) tax payments made by Nevada residents and non-gaming businesses are subsidized by the gaming industry; 2) economic diversification encourages non-gaming businesses and industries expand within Nevada; 3) new businesses and their supporting population demand additional public services; 4) additional public services require additional public revenues; and 5) because the gaming industry subsidizes tax payments by non-gaming businesses and residents, the level of services provided must decline, OR additional tax revenues must be generated (from existing or new sources). This argument is not without merit, and tends to invert the issue of sustainable tourism. Clearly the gaming industry offsets a portion of the tax liability that would otherwise be generated by residents or non-gaming 
businesses. This having been said, economic and fiscal data analyzed by the Monitoring Program suggest this is not true for all businesses (and the residents supported by the wages they pay), nor can it be equally applied at to all levels of government.

There are generally three groups that benefit from state and local government services: 1) residents, 2) businesses, and 3) visitors. These groups are also the primary sources of state and local government revenues, which are generated through taxes, fees, and other charges. At the state level, a large share of revenue is generated by the gaming/tourism industry. During 2003-04, gaming taxes, fees, and licenses contributed more than $\$ 714$ million dollars, or approximately $30 \%$ to the state of Nevada's general fund revenues. (Legislative Counsel Bureau, [20]) Gaming taxes, however, are not the largest generator of revenue for the state. Retail sales and use tax generated nearly $\$ 791$ million, or 33\% of the state's general fund revenues.

Worth noting is the fact that sales tax revenues have been increasing at a more rapid rate than gaming taxes. Much of this change in the revenue stream can be explained by the changes in visitor spending patterns mentioned earlier. A relatively smaller share of visitor dollars is being expended in gaming activities, and a larger share is being spent in retail, eating, and drinking outlets. The result is substantial sales tax revenues being derived from travelers. Visitor contributions to the tax base have been estimated at between 25 and $30 \%$ of total taxes collected (Governor's Task Force on Tax Policy in Nevada, [21]). The balance of state revenues is generated through a number of other taxes, fees, permits, and charges. They include, mining tax, insurance premium tax, excise taxes, a modified payroll tax, business license fees, and several others. The gaming/tourism industry's contributions to gaming taxes, retail sales taxes, and the various other levies, fees and charges has generated estimates that its total contribution to the state's own-source revenues is as high as 50 to $60 \%$. Based on these assertions, the argument is then presented that the gaming/tourism industry accounts for only $30 \%$ of employment, yet pays more than $50 \%$ of the taxes, fees, and charges that fund the state's expenditures. Therefore, they must be subsidizing revenues that would otherwise have been generated from residents and non-gaming business. A condition only exacerbated by economic development efforts.

While it would be irrational to suggest that gaming dollars are not a principal source of support for much of Nevada's growth since the 1930s, or that some level of subsidization takes place, Monitoring Program data suggest that policymakers should be cautious not to overstate the industry's contribution to overall tax receipts. The first issue that is not addressed is that of the visitor's demand for services. Even though the average visitor stays less than four days, they still utilize services like roads, police, and fire protection, and water and sewer. In effect, the more than 40 million visitors that Southern Nevada welcomes annually operate, at least in part, like residents. Assuming that the 1.8 million Clark County residents never vacationed during the year and the 40 million visitors stay an average of 3.6 days per trip, tourists account for roughly $17 \%$ of the adjusted gross population of Clark County, Nevada each year. 
Recognizing that visitors do not demand the full gamut of public services; to assume that they represent zero draw on public services would be perilous supposition.

A second consideration omitted in the discussion of gaming's subsidization of residents' and businesses' payments for public services is the portion of gaming taxes paid by residents. It is estimated that Nevada residents spend as much as $\$ 3.1$ billion annually in gaming activities each year. While resident spending represents less than $20 \%$ of Nevada's \$11 billion dollars in gross gaming revenue, they generate more than $\$ 200$ million in state tax collections annually.

A third consideration is the higher potential for social service cost stemming from gaming industry employees. While paying comparably high wages by national industry standards and some of the best benefits packages provided in any industry, tourism-related businesses pay average wages significantly lower than the statewide mean. Generally speaking, lower-income families tend to demand a greater level of public services. This point is particularly noteworthy when one considers the types of business that have been attracted to Nevada and Southern Nevada through publicly-sponsored economic diversification programs. Generally speaking, these programs require both higher-than-average wages and employee health benefits to qualify for assistance.

Perhaps most importantly the arguments outlined above have focused exclusively on state revenues, ignoring the very material collections of local governments. The majority of Nevada's public revenues, at any level of government, are sourced to three primary streams: 1) gaming tax, 2) retail sales and use tax; and 3) property tax. The state is funded more heavily from gaming and sales tax, while local governments are more dependent on property and sales tax. Figures 3 through 5 explore the relationship between inflation-adjusted public revenue per capita, visitor volume, and non-leisure and hospitality employment growth. While Monitoring Program data focus on Clark County activities, Nevada's local governments tend to be very similarly funded, allowing some preliminary generalizations to be drawn.

Figure 3 compares visitor volume and non-leisure and hospitality-related employment growth rates between 1995 and 2005. It indicates that non-leisure and hospitality-related employment growth has almost consistently outpaced increases in visitor volume during the past decade. Also included in Figure 3 are inflation-adjusted state revenues per capita. Intergovernmental transfers have been removed from these figures (to reflect the state's own-source revenue production) as have the estimated revenues attributable to tax increases imposed during the 2003 State Legislative Session. The trend here is also fairly clear, as inflation-adjusted revenues per capita have generally declined. The noteworthy exception is 2004 and 2005 when inflation-adjusted per capita yields improved. While additional study is required here, it is likely that the lower values returned during 2002 and 2003 were more a function of a soft economy following the recession of the early 2000s and the events of September 11, 2001; and, in turn, the 2004 and 2005 figures represented a rebound back to a more normalized trend line. 


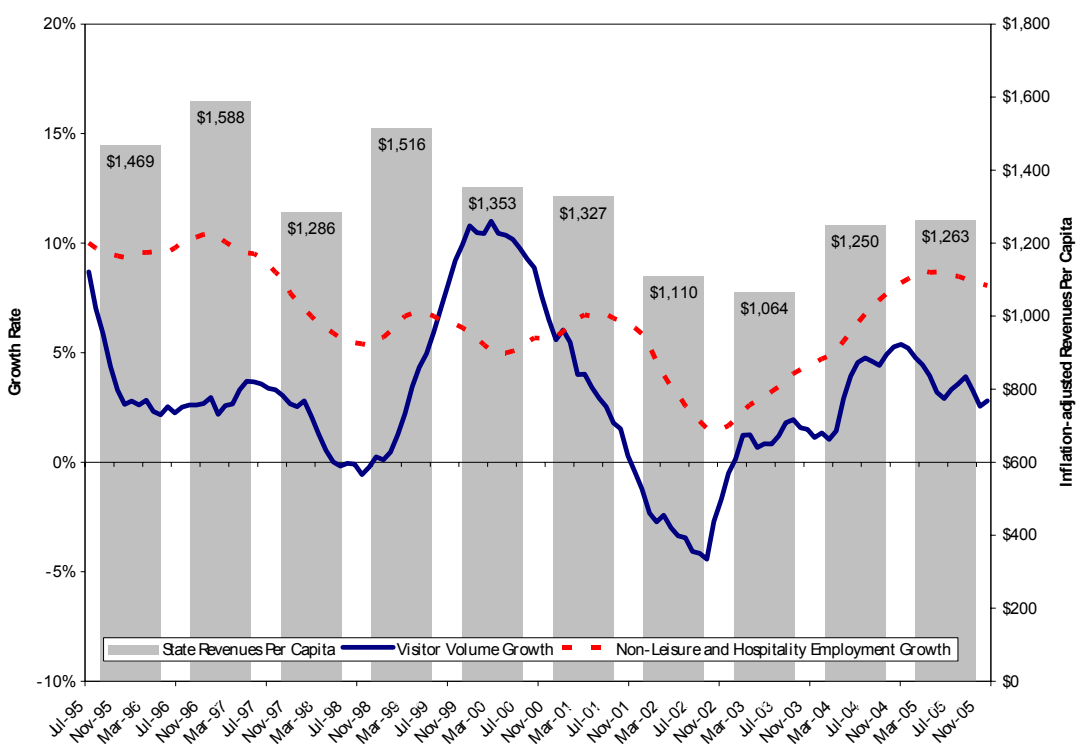

Figure 3: Visitation, employment growth and state revenues.

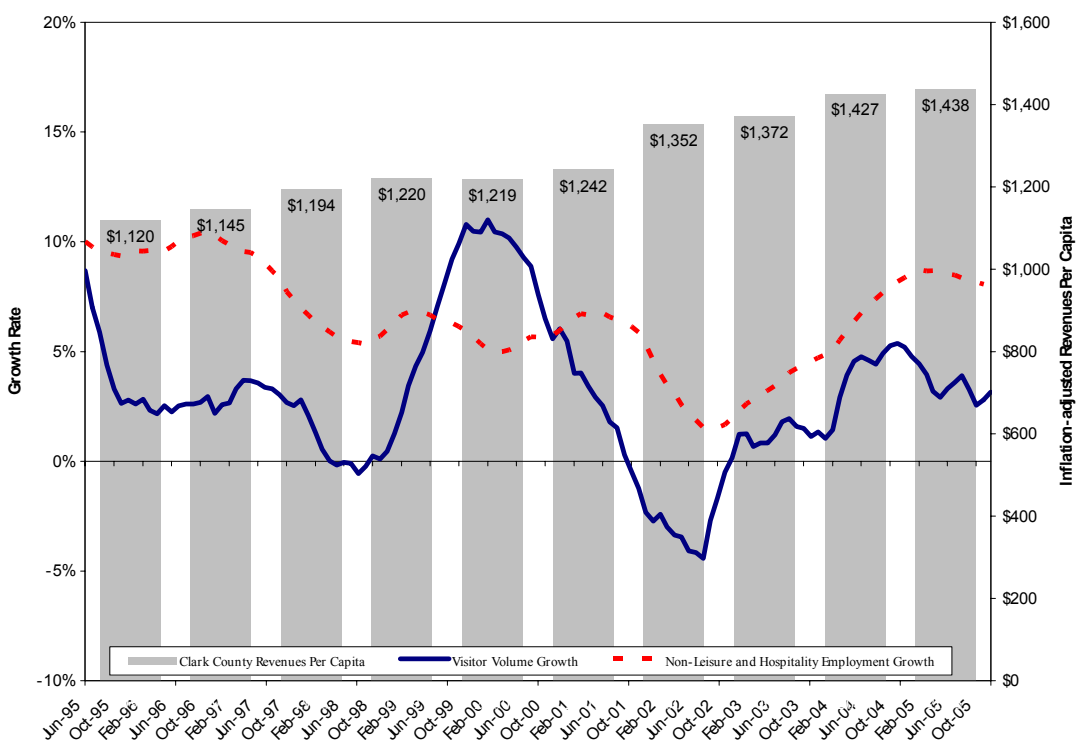

Figure 4: Visitation, employment growth and Clark County revenues. 


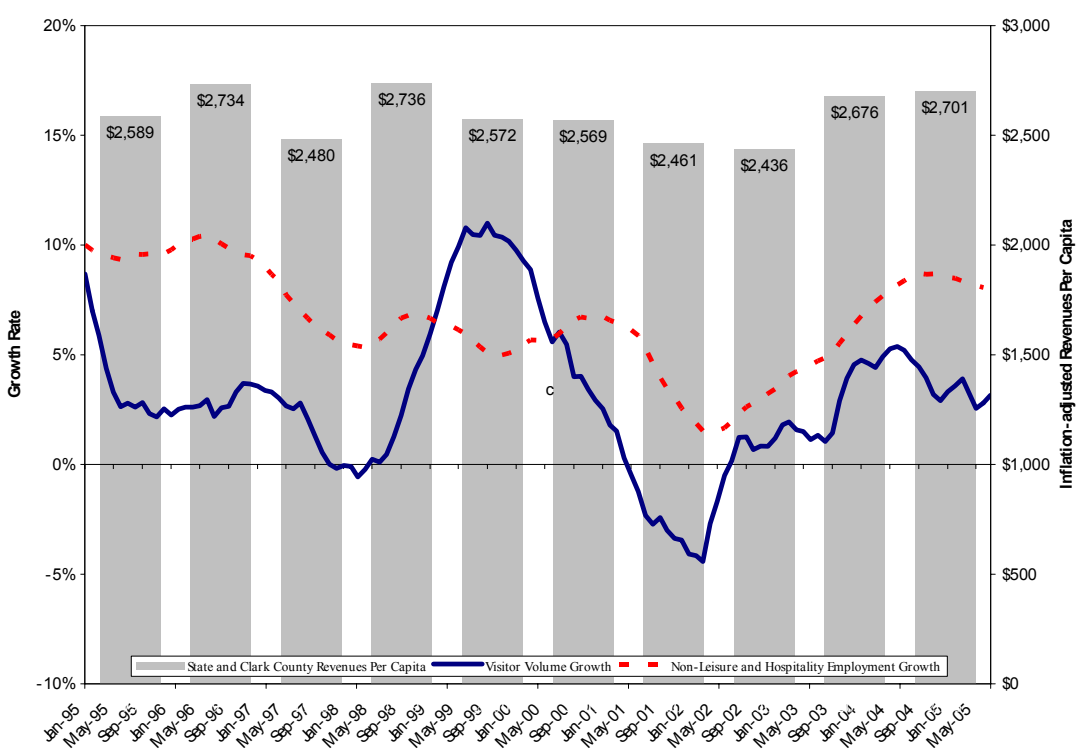

Figure 5: Visitation, employment growth and combined Clark County and state revenues.

Clearly Figure 3 would support the position that the sustainability of tourism is threatened by economic diversification. Figure 4, however, serves to muddy the waters. This figure focuses on Clark County revenues as opposed to state revenues and reflects fairly strong gains in inflation-adjusted per capita revenues. Where comparable per capita revenues have declined by $14 \%$ at the state level during the past decade, they have increased $28 \%$ at the local level. Figure 5, combines these dataset, and reflects a fair amount of revenue stability at all levels of government, even as the number of visitors per non-leisure and hospitality-related employee has increased (i.e., the economy has diversified). In fact, the standard deviation of the combined collections was only $4.3 \%$ of that average inflation-adjusted collections per capita reported during the decade. By contrast, this figure was $13 \%$ at the state level and $9 \%$ when looking only at Clark County.

\section{Monitoring impacts}

The potential risks associated with the shipment of radioactive waste have long been debated, and local governments have had mixed results in convincing the federal government that the potential "stigma" associated with such shipments could do harm, at some level, to the affected community. Clark County elected officials, residents and business owners have consistently been opposed to the shipment of high-level radioactive waste and spent nuclear fuel to a permanent repository in the region on that basis. Clark County sponsored the most recent 
study to assess the potential impacts to the gaming industry that may result from these shipments. The study, having been completed in 2001, has since resulted in the United States Department of Energy and the National Academy of Sciences both acknowledging the validity and possibility of stigma-related impacts to the region. Community surveys conducted over 20 years lend support to the finding that stigma-induced impacts, whether short-lived or long-term, can have a devastating effect on a community's economy, especially in a tourismdependent one like Las Vegas, where the notion of "perception is reality" is particularly marked. By monitoring both subtle and overt changes within the community indicators over time, and linking them back to community perceptions and priorities, Clark County will be able to demonstrate whether the general consensus with respect to impacts holds true, and to what extent community sustainability is affected both in the short- and long-term.

\section{Conclusion}

Two principal conclusions are drawn from this paper. First, tourism-dependent economies may have competing interests as it relates to the question of economic diversity, particularly where there is an asymmetrical distribution of revenues at different levels of government (e.g., state versus local). While economic diversity and stability are worthy goals, the sustainability of markets similar to Clark County, Nevada must also consider fiscal equity and the implications of structural change. Second, we would respectfully submit that the need for comprehensive community monitoring is heightened in such a market. The confluences of economic, fiscal, and social factors necessary to create a sustainable environment are many. The presence of an "early-warning system" helps separate true structural changes from the strong ebb and flow of a narrow, yet dynamic, economic unit.

\section{References}

[1] Urban Environmental Research. 2002. Clark County Impact Assessment Report. Clark County Comprehensive Planning, Clark County, Nevada.

[2] Conway, S. and Navis, I. 2004. "Impact Assessment and Public Outreach Strategies for Local Governments."

[3] Bybee, S. and Aguero, J. 1999. The Hospitality Industries Impact on the State of Nevada. University of Nevada Las Vegas, International Gaming Institute. Prepared for the Federal Gaming Impact Study Commission.

[4] Urban Land Institute. 1997 Livable Las Vegas: Managing Growth in the Las Vegas Valley, Washington, DC.

[5] Southern Nevada Strategic Planning Authority. 1999. "Planning for our Second Century," Final Strategic Plan. Clark County, Nevada.

[6] Nevada Gaming Control Board, 2005. "Statistics for Clark County Nonrestricted Gaming Licensees with \$1 Million or More in Gross Gaming Revenue.” Nevada Gaming Abstract. Carson City, Nevada. 
[7] San Diego Tribune. 1988. "Texas Rises Slowly from Hard Times 'CanDo' Spirits Battle Adversity With Diversity.” The San Diego Tribune. San Diego, Ca. (Quoting Mr. Steve Klinkerman, financial writer for the Dallas-Times Herald).

[8] Halkais, M. and Brown, S. 1984. "Healthy \& Wealthy in the Dallas-Fort Worth Area, Economic Diversity is the Rule and a Major Reason for Growth." The Dallas Morning News.

[9] Wallace, J. A. 1993. "New Beginning How They Battled Back From the Big Boeing Bust of '70s." Seattle Post-Intelligencer. Seattle, Washington.

[10] Dow Jones, 1982. "Boeing Layoffs Threaten to Cripple Seattle's Economy." Dow Jones Service-Edited Wall Street Journal Stories

[11] Chicago Tribune. 1993 "Seattle Braces for Boeing Slump," Chicago Tribune. Chicago, Illinois.

[12] Blackford, M. 1998. Business, Government, Tourism, and the Environment: Maui in the 1980s and 1990s. Business \& Economic History.

[13] Jones, T. 1998. "Resisting Progress in Molokai: Hard Times in Paradise. Los Angles Times. Los Angeles, CA.

[14] Ybarra, M.J. 1994. "Tourists Find Maui Heavenly, but Locals Tend to Disagree.” Dow-Jones News Service-Edited Wall Street Journal Stories.

[15] Malizia, EE, et al. 1993. "The Influence of Economic Diversity on Unemployment \& Stability." Journal of Regional Science. Blackwell Publishing.

[16] Norse, H. 1968. Regional Economics. New York: Praeger.

[17] Kort, J.R. 1981. "Regional Economic Instability and Industrial Diversification in the U.S." Land Economics.

[18] Wagner, J., and Deller, S. 1998. "Measuring the Effects of Economic Diversity on Growth and Stability." Land Economics.

[19] Siegel; P. et al. 1995. "Regional Economic Diversity and Diversification." Growth and Change."

[20] Nevada Legislative Counsel Bureau, Fiscal Division. 2005. 2005 Fiscal Appropriation Report. Nevada State Legislature. Carson City, Nevada.

[21] Governor's Task Force on Tax Policy in Nevada, 2002. Analysis of Fiscal Policy in Nevada. ACR 1 of the $17^{\text {th }}$ Special Session, 2001-02. Carson City, Nevada.

[22] Los Angeles Business Journal. "Accent on Diversity Spells Growth for San Antonio Economy." Los Angeles Business Journal. Los Angeles, California. 